\title{
PENGARUH PENGEMBANGAN KARIR DAN KOMPETENSI TERHADAP KINERJA GURU DI SMK MANAJEMEN PENERBANGAN MEDAN
}

\author{
${ }^{1}$ Julkarnain, ${ }^{2}$ Mintarsih \\ ${ }^{1,2}$ Universitas Islam Sumatera Utara \\ julkarnain@fe.uisu.ac.id, ${ }^{2}$ mintar.sih@gmail.com
}

\begin{abstract}
The purpose of the study was to determine the development progress towards teachers in the Medan Aviation Management Vocational School. To determine the effect of competence on the performance of teachers in SMK Flight Management Medan. To find out career development and competence on teacher performance in SMK Flight Management Medan. The population is all teachers obtained by 41 people. The sampling technique is total sampling. The research results obtained from positive and significant career development on teacher performance. Positive competence does not significantly influence teacher performance. Improved teacher performance significantly and significantly to teacher performance.
\end{abstract}

Keywords: Development, Competency, Performance.

ABSTRAK : Tujuan penelitian untuk mengetahui pengaruh pengembangan karir terhadap kinerja Guru di SMK Manajemen Penerbangan Medan. Untuk mengetahui pengaruh kompetensi terhadap kinerja Guru di SMK Manajemen Penerbangan Medan.Untuk mengetahui pengaruh pengembangan karir dan kompetensi terhadap kinerja guru di SMK Manajemen Penerbangan Medan. Populasi adalah seluruh guru yang berjumlah 41 orang. Teknik pengambilan sampel adalah total sampling. Hasil penelitian diperoleh bahwa pengembangan karir berpengaruh positif dan signifikan terhadap kinerja guru. Kompetensi berpengaruh positif tidak signifikan terhadap kinerja guru. Pengembangan karir dan kompetensi secara simultan berpengaruh positif dan signifikan terhadap kinerja guru.

Kata Kunci :Pengembangan Karir, Kompetensi, Kinerja.

\section{Pendahuluan}

Kinerja perusahaan yang optimal dapat dilakukan dengan salah satu upaya yaitu memerlukan sumber daya manusia yang berkualitas. Manajemen Sumber Daya Manusia (MSDM) merupakan bagian dari manajemen keorganisasian yang memfokuskan diri pada unsur sumber daya manusia. Manajemen sumber daya manusia mempunyai tugas untuk mengelola unsur manusia secara baik agar diperoleh tenaga kerja yang puas akan pekerjaannya. Setiap perusahaan menetapkan tujuan-tujuan tertentu yang ingin dicapai dalam hal memberdayakan sumber dayanya termasuk sumber daya manusia dengan cara menerapkan sumber daya manusia yang tepat untuk organisasi atau perusahaannya secara tepat dan efektif.

Kinerja atau performance merupakan gambaran mengenai tingkat pencapaian pelaksaan suatu program kegiatan atau kebijakan dalam mewujudkan sasaran, tujuan, visi, dan misi organisasi yang dituangkan melalui perencanaan strategis suatu organisasi. Kinerja dapat diketahui dan diukur jika individu atau sekelompok karyawan telah mempunyai kriteria atau standar keberhasilan tolak ukur yang telah ditetapkan oleh organisasi. Oleh karena itu, jika tanpa tujuan dan target yang ditetapkan dalam pengukuran, maka kinerja pada seseorang atau kinerja organisasi tidak mungkin dapat diketahui bila tidak ada tolak ukur keberhasilannya. (Moeheriono, 2012: 95).

Pengembangan karir sangat penting bagi suatu organisasi, karena karier merupakan kebutuhan yang harus terus dikembangkan dalam diri seorang guru sehingga mampu memotivasi guru untuk meningkatkan kinerjanya. Pengembangan karier meliputi setiap aktivitas untuk mempersiapkan seseorang untuk menempuh jalur karier tertentu. Suatu rencana karier yang telah dibuat oleh seseorang pekerja harus disertai oleh suatu tujuan karier yang realistis. Karena perdefinisi perencanaan, termasuk perencanaan karier. Menurut Sunyoto (2012:164) perencanaan 
karier adalah proses yang dilalui oleh individu karyawan untuk mengindetifikasi dan mengambil langkah-langkah untuk mencapai tujuan kariernya.

Fenomena yang terjadi dalam pengembangan karier pada SMK Penerbangan Manajemen Penerbangan Medan tidak adanya perlakuan yang adil, kurangnya keperdulian para atasan langsung, tidak adanya informasi tentang berbagai peluang promosi di SMK Manajemen Penerbangan Medan, tidak adanya minat para pegawai untuk dipromosikan dan tidak adanya tingkat kepuasaan.

Sadili Samsudin (2016:133) mendefinisikan pengembangan karir adalah suatu usaha meningkatkan kemampuan teknis, teoritis, konseptual, dan moral karyawan sesuai dengan kebutuhan pekerjaan/jabatan melalui pendidikan dan latihan.

Kompetensi diartikan sebagai kemampuan untuk melaksanakan atau melakukan suatu pekerjaan atau tugas yang dilandasi oleh keterampilan dan pengetahuan kerja yang dituntut oleh pekerjaan tersebut. Dengan demikian kompetensi menunjukkan keterampilan atau pengetahuan yang dicirikan oleh profesionalisme dalam suatu bidang tertentu sebagai suatu yang terpenting. Kompetensi sebagai karakteristik seseorang berhubungan dengan kinerja yang efektif dalam suatu pekerjaan atau situasi Wibowo (2017:86).

Fenomena kompetensi di SMK Manajemen Penerbangan Medan, yaitu kurangnya pengetahuan (knowledge), kurangnya pemahaman (understanding), tidak mempunyai kemampuan/keterampilan (skill), kurangnya nilai, tidak adanya sikap (attitude), kurangnya minat (interest)

Kompetensi oleh Spencer yang dikutip oleh Moeheriono (2014:5) adalah sebagai karakteristik yang mendasari seseorang berkaitan dengan efektivitas kinerja individu dalam pekerjaannya atau karakteristik dasar individu yang memiliki hubungan kausal atau sebagai sebab akibat dengan kriteria yang dijadikan acuan. Menurut Spencer ini, kompetensi terletak pada bagian dalam setiap manusia dan selamanya ada pada kepribadian seseorang yang dapat memprediksikan tingkah laku dan performansi secara luas pada semua situasi dan tugas pekerjaan.

Distyawaty (2017) menunjukkan bahwa kompetensi dan pengembangan karier secara simultan berpengaruh signifikan tehadap kinerja. Kompetensi berpengaruh signifikan terhadap kinerja. Pengembangan karir berpengaruh signifikan terhadap kinerja Aparatur pengawas Inspektorat Daerah Provinsi Sulawesi Tengah. Yohana Padendenan (2017) menunjukkan bahwa Pengembangan Karir Terhadap Kinerja guru pada Dinas Pendidikan dan Kebudayaan Kabupaten Sigi.

Berdasarkan penjelasan di atas maka dilakukan penelitian lebih lanjut dengan judul penelitian yang diajukan adalah : "Pengaruh Pengembangan Karir dan Kompetensi terhadap Kinerja Guru SMK Manajemen Penerbangan Medan.

Setiap guru memiliki kemampuan dan ketrampilan masing-masing dalam mencapai kinerja yang ditentukan. Tergantung pada seberapa tanggungjawab mereka untuk melaksanakan tugas yang diberikan. Pekerjaan atau tugas yang diberikan, biasanya akan mempunyai kurun waktu tertentu dalam masa penyelesaiannya, dan guru dituntut untuk memenuhinya. Landasan sesungguhnya dalam suatu perusahan adalah kinerja. Jika tidak ada kinerja maka seluruh tujuan perusahaan tidak dapat tercapai.

\subsection{Pengukuran Kinerja}

Pengukuran terhadap kinerja perlu dilakukan untuk mengetahui apakah selama pelaksanaan kinerja terdapat deviasi dari rencana yang telah ditentukan apakah kinerja dapat dilakukan sesuai jadwal waktu yang ditentukan atau apakah hasil kinerja telah tercapai sesuai dengan yang diharapkan. (Wibowo, 2017: 155).

Pengukuran kinerja yang tepat dapat dilakukan, antara lain:

a. Memastikan bahwa persyaratan yang diinginkan pelanggan telah terpenuhi.

b. Mengusahakan standar kinerja untuk menciptakan perbandingan.

c. Mengusahakan jarak bagi orang untuk memonitor tingkat kinerja

d. Menetapkan arti penting masalah kualitas dan menentukan apa perlu prioritas perhatian.

e. Menghindari konsekuensi dari rendahnya kualitas

f. Mempertimbangkan penggunaan sumber daya

g. Mengusahakan umpan balik untuk mendorong usaha perbaikan. (Wibowo, 2017: 155-156).

\subsection{Hubungan Pengembangan Karir dan Kompetensi terhadap Kinerja}

Kompetensi merupakan bagian dari kepribadian yang melekat pada diri seseorang, 
yang ditunjukkan dengan watak atau karakter serta konsep diri yang memprediksi prilaku keahlian, tindakan, yang selanjutnya dapat memprediksi kinerja kerja. Dengan kompetensi menghasilkan tindakan yang didasari dengan adanya maksud atau tujuan. Menurut Mc. Lelland (dalam Moeheriono, 2012: 6) kompetensi adalah karakteristik dasar personel yang menjadi faktor tertentu sukses tidaknya seseorang dalam mengerjakan suatu pekerjaan atau pada situasi tertentu.

Kompetensi menjadi sesuatu yang penting karena kompetensi erat hubungannya dengan kinerja. Dengan adanya kompetensi dalam setiap diri pegawai diharapkan dapat meningkatkan kinerja dengan maksimal. Faktor eksternal yang dapat meningkatkan kinerja yaitu Pengembangan karir. Kompetensi dapat digunakan dalam menciptakan pengembangan karir bagi pegawai untuk mencapai jenjang karir yang sesuai dengan potensi yang dimiliki. Salah satu masalah yang ada dilapangan bahwa pegawai menginginkan adanya perbaikan karir atau pengembangan karir guna mendapatkan titik aman untuk mendapatkan status menjadi pegawai tetap, hal ini menjadi salah satu solusi untuk meningkatkan kinerja pegawai melalui pengembangan karir.

\subsection{Pengembangan Karir}

Pengembangan karier sangat penting bagi suatu organisasi, karena karier merupakan kebutuhan yang harus terus dikembangkan dalam diri seorang pegawai sehingga mampu memotivasi pegawai untuk meningkatkan kinerjanya. Pengembangan karier meliputi setiap aktivitas untuk mempersiapkan seseorang untuk menempuh jalur karier tertentu. suatu rencana karier yang telah dibuat oleh seseorang pekerja harus disertai oleh suatu tujuan karier yang realistis,.

Menurut Mangkunegara

"Pengembangan karir adalah perbaikan pribadi yang diusahakan oleh seseorang untuk mencapai rencana karir pribadi”.

Menurut Widodo (2015:53), "Pengembangan karier adalah serangkaian aktivitas sepanjang hidup yang berkontribusi pada eksplorasi, pemantapan, keberhasilan dan pemenuhan karier seseorang.

Menurut Rivai dan Sagala (2013:274), mengemukakan bahwa, pengembangan karir adalah proses peningkatan kemampuan kerja individu yang dicapai dalam rangka mencapai karir yang diinginkan..

Dari paparan berbagai teori mengenai
Pengembangan karir dari berbagai ahli, dapat ditarik kesimpulan bahwa pengembangan karir adalah aktivitasaktivitas dari pegawai di dalam meningkatkan kompetensi demi mencapai tujuan karir yang diinginkan secara maksimal dan berkelanjutan dengan perusahaan sebagai penyedia fasilitas pengembangan karir.

\subsection{Faktor-faktor yang Mempengaruhi Pengembangan Karir}

Menurut Siagian (2012:207), faktor yang mempengaruhi pengembangan karir adalah sebagai berikut:

a. Perlakuan yang adil dalam berkarir Perlakuan yang adil itu hanya bisa terwujud apabila kriteria promosi didasarkan pada pertimbangan-pertimbangan yang objektif, rasional dan diketahui secara luas dikalangan pegawai.

b. Keperdulian para atasan langsung Para pegawai pada umumnya mendambakan keterlibatan atasan langsung mereka dalam perencanaan karir masing-masing. Salah satu bentuk keperdulian itu adalah memberikan umpan balik kepada para pegawai tentang pelaksanaan tugas masing-masing sehingga para pegawai tersebut mengetahui potensi yang perlu diatasi. Pada gilirannya umpan balik itu merupakan bahan penting bagi para pegawai mengenai langkah awal apa yang perlu diambilnya agar kemungkinannya untuk dipromosikan menjadi lebih besar.

c. Informasi tentang berbagai peluang promosi Para pegawai pada umumnya mengharapkan bahwa mereka memiliki akses kepada informasi tentang berbagai peluang untuk dipromosikan. Akses ini sangat penting terutama apabila lowongan yang tersedia diisi melalui proses seleksi internal yang sifatnya kompetitif. Jika akses demikian tidak ada atau sangat terbatas para pekerja akan mudah beranggapan bahwa prinsip keadilan dan kesamaan dan kesempatan untuk dipertimbangkan, untuk dipromosikan tidak diterapkan dalam organisai.

d. Minat untuk dipromosikan Pendekatan yang tepat digunakan dalam hal menumbuhkan minat para pekerja untuk pengembangan karir ialah pendekatan yang fleksibel dan proaktif. Artinya, minat untuk mengembangkan karir sangat individualistic sifatnya. Seovrang pekerja memperhitungkan berbagai faktor seperti usia, jenis kelamin, jenis dan sifat pekerjaan sekarang. Pendidikan dan pelatihan yang ditempuh, jumlah tanggungan dan 
berbagai variabel lainnya. Berbagai faktor tersebut dapat berakibat pada besarnya minat sesorang mengembangkan karirnya.

e. Tingkat kepuasaan Meskipun secara umum dapat dikatakan bahwa setiap orang ingin meraih kemajuan, termasuk dalam meniti karir, ukuran keberhasilan yang digunakan memang berbeda-beda. Perbedaan tersebut merupakan akibat tingkat kepuasaan dalam konteks terakhir tidak selalu berarti keberhasilan mencapai posisi yang tinggi dalam organisasi, melainkan pula berarti bersedia menerima kenyataan bahwa, karena berbagai faktor pembatasan yang dihadapi oleh seseorang, pekerja"puas"apabila ia dapat mencapai timgkat tertentu dalam karir nya meskipun tidak banyak anak tangga karir yang berhasil dinaikinya. Tegasnya, seseorang bisa puas karena mengetahui bahwa apa yang dicapainya itu sudah merupakan hasil yang maksimal dan berusaha mencapai anak tangga yang lebih tinggi akan merupakan usaha yang sia-sia karena mustahil untuk dicapai

\subsection{Hubungan Pengembangan Karir Terhadap Kinerja}

Menurut Veithzal Rivai dan Sagala (2013:71) salah satu faktor yang mempengaruhi kinerja pegawai adalah pengembangan karir yang baik, pengembangan karir adalah usaha yang dilakukan oleh individu dalam meningkatkan kinerja individu yang dicapai dalam rangka mencapai karirnya, secara formal dan berkelanjutan dengan difokuskan pada peningkatan dan penambahan kemampuan seorang pekerja. Jadi pengembangan karir bukan sekedar berarti promosi ke jabatan atau posisi yang lebih tinggi, tetapi merupakan dorongan atau motivasi untuk maju dalam bekerja dilingkungan suatu organisasi jika karir seorang berjalan dengan baik artinya mengalami peningkatan akan membawa pengaruh pada karir pegawai.

Adanya uraian di atas dapat peneliti simpulkan bahwa pengembangan karirternayta berpengaruh dalam mengatur tinggi atau rendahnya kinerja pegawai, karena dengan pengembangan karir bagi pegawai yang tepat, mampu membantu organisasi atau instansi mencapai tujuannya tersebut.Tidak hanya membantu organisasi atau instansi, pengembangan karir yang tepat akan bermanfaat serta menghasilkan kinerja personality yang relatif tinggi, dan tinggi rendahnya variabel pengembangan karir akan berpengaruh secara signifikan dan positif terhadap kinerja pegawai.

\subsection{Kompentensi}

Setiap perusahaan dibentuk untuk mencapai tujuan tertentu dan apabila tercapai, barulaah dapaat disebut sebagai sebuah keberhasilan.Untuk mencapai keberhasilan, diperlukan landasan yang kuat dan salah satunya adalah kompetensi. Kompetensi menjadi sangat berguna untuk membaantu perusahaan dalam menciptakan budaya kinerja tinggi. Kompetensi juga sangat diperlukan dalam setiap proses sumber daya manusia, seleksi pegawai, manajemen kinerja, perencanaan dan sebagainya. Demikian pula diperlukan untuk mengomunikasikan nilai dan standar perusahaan, menyeleksi, dan merekrut tenaga kerja, menilai dan mengembangkan tenaga kerja, mengembangkan pemimpin, mengelola proses perencanaan, membangun dasar untuk strategi pelatihan, dan membentuk proses kompensasi.

Para ahli umumnya memberikan pandangan yang bervariasi tentang kompetensi. Kompetensi adalah kapasitas yang dimiliki pegawai, yang mengarah kepada perilaku yang sesuai dengan tuntutan pekerjaan serta sesuai dengan ketetapan organisasi yang pada gilirannya akan membawa hasil seperti yang dinginkan. Boyatzis (Amstrong, 2009 dalam Priansa, 2018: 253).

Kompetensi adalah karakteristik mendasar seseorang yang menghasilkan kinerja unggul dan efektif dalam suatu pekerjaan. (Klemp dalam Sudarmanto, 2014:45). Kompetensi adalah suatu karakteristik dasar dari seseorang yang memungkinkannya memberikan kinerja unggul dalam pekerjaan, peran, atau situasi tertentu. (Boulter, Dalziel, dan Hill, 2003 dalam Sutrisno, 2016:203).

\subsection{Karakteristik Kompetensi}

Setiap perusahaan dibentuk untuk mencapai tujuan tertentu dan apabila tercapai, barulah dapat disebut sebagai sebuah keberhasilan.Untuk mencapai keberhasilan, diperlukan landasan yang kuat dan salah satunya adalah kompetensi. Kompetensi menjadi sangat berguna untuk membaantu perusahaan dalam menciptakan budaya kinerja tinggi. Kompetensi juga sangat diperlukan dalam setiap proses sumber daya manusia, seleksi pegawai, manajemen kinerja, perencanaan dan sebagainya. Demikian pula diperlukan untuk mengomunikasikan nilai dan standar perusahaan, menyeleksi, dan merekrut tenaga kerja, menilai dan mengembangkan tenaga kerja, mengembangkan pemimpin, mengelola proses perencanaan, membangun 
dasar untuk strategi pelatihan, dan membentuk proses kompensasi.

Adapun 5 (lima) karakteristik kompetensi yaitu Motives, Traits, Self Concept, Knowledge, dan Skills.

a. Motives, adalah sesuatu dimana sesorang secara konsisten berfikir sehingga ia melakukan tindakan.

Traits, adalah watak yang membuat orang untuk berperilaku atau bagaimana seseorang merespon sesuatu dengan cara tertentu. Sebagai contoh seperti percaya diri, kontrol diri, ketabahan atau daya tahan.

b. Self Concept, adalah sikap dan nilai-nilai yang dimiliki seseorang. Sikap dan nilai diukur melalui tes kepada responden untuk mengetahui nilai yang dimiliki seseorang dan apa yang menarik bagi seseorang untuk melakukan sesuatu.

c. Knowledge, adalah informasi yang dimiliki seseorang untuk bidang tertentu. Pengetahuan

Tabel. 1

Hasil Uji Multikolinearitas

\begin{tabular}{|c|c|c|c|c|}
\hline \multirow[b]{2}{*}{ Model } & \multicolumn{2}{|c|}{$\begin{array}{c}\text { Unstandardized } \\
\text { Coefficients }\end{array}$} & \multicolumn{2}{|c|}{ Collinearity Statistics } \\
\hline & B & Std. Error & Tolerance & VIF \\
\hline (Constant) & 3.463 & 6.068 & & \\
\hline Pengembangan Karir & .652 & .162 & .702 & 1.425 \\
\hline Kompetensi & .302 & .150 & .702 & 1.425 \\
\hline
\end{tabular}

Dependent variable : kinerja

Sumber: Data Diolah dengan SPSS, 2020

Berdasarkan hasil pengujian multikolinearitas pada tabel di atas, dengan ketentuan dapat dilihat bahwa nilai tolerance pengembangan karir sebesar $0,10>0.702$ dengan nilai VIF sebesar $1.425<10$ dan untuk kompetensi memiliki nilai tolerance sebesar $0.702>0,1$ dengan nilai VIF sebesar $1.425<10$ sehingga dapat disimpulkan bahwa tidak terdapat gejala multikolinearitas

Tabel. 2

Hasil Regresi Linear Berganda

\begin{tabular}{|c|c|c|c|c|c|}
\hline & \multirow[b]{2}{*}{ Model } & \multicolumn{2}{|c|}{$\begin{array}{c}\text { Unstandardized } \\
\text { Coefficients }\end{array}$} & \multirow[b]{2}{*}{$\mathrm{t}$} & \multirow[b]{2}{*}{ Sig. } \\
\hline & & B & Std. Error & & \\
\hline 1 & (Constant) & 3.463 & 6.068 & .571 & .572 \\
\hline & Pengembangan Karir & 652 & .162 & 4.018 & .000 \\
\hline & Kompetensi & .302 & .150 & 2.013 & .051 \\
\hline
\end{tabular}

Dependent variable : kinerja guru

Sumber: Data Diolah dengan SPSS, 2020 merupakan kompetensi yang kompleks. Tes pengetahuan mengukur kemampuan peserta untuk memilih jawaban yang paling benar tetapi tidak bias melihat apakah sesorang dapat melakukan pekerjaan berdasarkan pengetahuan yang dimilikinya.

d. Skills, adalah kemampuan untuk melaksanakan suatu tugas tertentu baik secara fisik maupun mental. Dengan mengetahui tingkat kompetensi maka perencanaan sumber daya manusia akan lebih baik hasilnya. (Spencer, 1993 dalam Sutrisno, 2016: 206207).

\section{ANALISIS DAN EVALUASI}

2.1. Uji Multikolinearitas

Adapun hasil pengujian multikolinearitas dalam penelitian ini dapat dilihat pada tabel berikut: pada model regresi yang digunakan dalam penelitian ini dan model regresi telah memenuhi syarat uji multikolinearitas.(Ghozali, 2016:92).

\subsection{Hasil Regresi Linear Berganda}

Adapun hasil regresi linear berganda dalam penelitian ini dapat dilihat pada tabel berikut: 
Berdasarkan hasil regresi linear berganda pada tabel di atas maka dapat dibuat persamaan sebagai berikut:

$$
\mathrm{Y}=3.463+0.652 \mathrm{X}_{1}+0.302 \mathrm{X}_{2}
$$

Berdasarkan hasil persamaan tersebut maka dapat diuraikan penjelasan sebagai berikut:

a. Nilai konstanta sebesar 3.463 memberikan arti

bahwa jika secara keseluruhan nilai pengembangan karir dan kompetensi sebesar 3.463

b. Nilai koefisien pengembangan karir sebesar 0.652 memberikan arti bahwa jika nilai pengembangan karir naik sebesar $1 \%$ maka nilai kinerja guru juga akan naik sebesar $65.2 \%$. Nilai koefisien pengembangan karir yang positif memberikan arti bahwa pengembangan karir memberikan pengaruh positif terhadap kinerjaa guru.

c. Nilai koefisien kompetensi sebesar 0.302 memberikan arti bahwa jika nilai kompetensi naik sebesar $1 \%$ maka nilai kinerja guru juga akan naik sebesar $30.2 \%$. Nilai koefisien kompetensi yang positif memberikan arti bahwa kompetensi memberikan pengaruh positif terhadap kompetensi.

\section{Hasil Uji Hipotesis}

\subsection{Hasil Uji Signifikansi Parsial (Uji-t)}

Adapun hasil dari pengujian signifikansi parsial (uji-t) dalam penelitian ini dapat dilihat pada tabel berikut:

Tabel. 3

Hasil Uji Signifikansi Parsial (Uji-t)

\begin{tabular}{|c|c|c|c|c|c|}
\hline \multirow[b]{2}{*}{ Model } & \multicolumn{2}{|c|}{$\begin{array}{c}\text { Unstandardized } \\
\text { Coefficients }\end{array}$} & \multirow{2}{*}{$\begin{array}{l}\text { Standardized } \\
\text { Coefficients } \\
\text { Beta }\end{array}$} & \multirow[b]{2}{*}{$\mathrm{t}$} & \multirow[b]{2}{*}{ Sig. } \\
\hline & $\mathrm{B}$ & Std. Error & & & \\
\hline (Constant) & 3.463 & 6.068 & & .571 & .572 \\
\hline $\begin{array}{c}\text { Pengembangan } \\
\text { Karir }\end{array}$ & .652 & .162 & .538 & 4.018 & .000 \\
\hline Kompetensi & .302 & .150 & .270 & 2.013 & .051 \\
\hline
\end{tabular}

Dependent variable : kinerjaa guru

Sumber: Data Diolah dengan SPSS, 2020

Berdasarkan hasil pengujian signifikansi parsial (uji-t) pada tabel di atas dapat dilihat bahwa nilai $t_{\text {hitung }}$ pengembangan karir sebesar $4.018>\mathrm{t}_{\text {tabel }} 1.684$ dengan tingkat signifikansi sebesar $0,000<0,05$ sehingga dapat disimpulkan bahwa dalam penelitian ini pengembangan karir berpengaruh positif dan signifikan terhadap kinerja Guru SMK Manajemen Penerbangaan Medan. Selanjutnya untuk kompetensi memiliki nilai $t_{\text {hitung }}$ sebesar $2.013>t_{\text {tabel }} 1.684$ dengan tingkat signifikansi sebesar $0.051>0,05$ sehingga dapat disimpulkan bahwa dalam penelitian ini kompetensi berpengaruh positif tidak signifikan terhadap kinerja guru SMK Manajemen Penerbangaan Medan.

\subsection{Hasil Uji Signifikansi Simultan (Uji-F)}

Adapun hasil dari pengujian signifikansi simultan (uji-F) dalam penelitian ini dapat dilihat pada tabel berikut:

Tabel. 4

Hasil Uji Signifikansi Simultan (Uji-F) ANOVA $^{b}$

\begin{tabular}{|c|c|c|c|c|c|c|}
\hline \multicolumn{2}{|r|}{ Model } & $\begin{array}{l}\text { Sum of } \\
\text { Squares }\end{array}$ & df & Mean Square & $\mathrm{F}$ & Sig. \\
\hline \multirow[t]{3}{*}{1} & Regression & 213.967 & 2 & 106.984 & 20.692 & $.000^{\mathrm{a}}$ \\
\hline & Residual & 196.472 & 38 & 5.170 & & \\
\hline & Total & 410.439 & 40 & & & \\
\hline
\end{tabular}

a. Predictors: (Constant), Kompetensi, Pengembangan Karir

b. Dependent Variable: Kinerja 
Berdasarkan hasil pengujian signifikansi simultan (uji-F) pada tabel di atas dapat dilihat bahwa nilai $\mathrm{F}_{\text {hitung }}$ sebesar $20.692>\mathrm{F}_{\text {tabel }} 3.24$ dengan tingkat signifikansi sebesar $0,000<0,05$ sehingga dapat disimpulkan bahwa dalam penelitian ini secara simultan pengembangan karir dan kompetensi berpengaruh positif dan signifikan terhadap kinerja guru SMK Manajemen Penerbangaan Medan

\subsection{Hasil Uji Koefisien Determinasi $\left(\mathbf{R}^{2}\right)$}

Adapun hasil pengujian koefisien determinasi $\left(\mathrm{R}^{2}\right)$ dalam penelitian ini dapat dilihat pada tabel berikut:

Tabel. 5

Hasil Uji Koefisien Determinasi $\left(\mathbf{R}^{2}\right)$

\begin{tabular}{|c|c|r|r|r|}
\hline Model & \multicolumn{1}{|c|}{$\mathrm{R}$} & R Square & $\begin{array}{c}\text { Adjusted R } \\
\text { Square }\end{array}$ & $\begin{array}{c}\text { Std. Error of } \\
\text { the Estimate }\end{array}$ \\
\hline 1 & $.722^{\mathrm{a}}$ & .521 & .496 & 2.27383 \\
\hline
\end{tabular}

a. Predictors: (Constant), Kompetensi, Pengembangan Karir

b. Dependent Variable: Kinerja

Sumber: Data Diolah dengan SPSS, 2020

Berdasarkan hasil pengujian koefisien determinasi $\left(\mathrm{R}^{2}\right)$ pada tabel di atas dapat dilihat bahwa nilai $R$ Square sebesar 0.521 sehingga dapat disimpulkan bahwa dalam penelitian ini pengembangan karir dan kompetensi memiliki kontribusi terhadap kinerja guru sebesar 52.1\% dan sisanya sebesar $47.9 \%$ dipengaruhi oleh faktor lain yang tidak diteliti dalam penelitian ini. Koefisien determinasi berkisaran antara nol sampai satu $\left(0 \leq \mathrm{R}^{2} \geq 1\right)$. Jika $\mathrm{R}^{2}$ semakin besar (mendekati satu), maka dapat dinyatakan berpengaruh variabel bebas (X) besar terhadap variabel terikat $(\mathrm{Y})$. Hal ini berarti model yang digunakan semakin kuat untuk menerangkan pengaruh variabel bebas (X) terhadap variabel terikat (Y) dan demikian sebaliknya.

\section{KESIMPULAN}

Berdasarkan hasil dari penelitian ini, maka dapat diuraikan kesimpulan sebagai berikut:

1. Pengembangan karir berpengaruh positif dan signifikan terhadap kinerja guru di SMK Manajemen Penerbangan Medan.

2. Kompetensi berpengaruh positif tidak signifikan terhadap kinerja guru di SMK Manajemen Penerbangan Medan.

3. Pengembangan karir dan kompetensi secara simultan berpengaruh positif dan signifikan terhadap kinerja guru di SMK Manajemen Penerbangan Medan.

\section{DAFTAR PUSTAKA}

\section{Buku}

Fahmi, Irham. 2017. Manajemen Sumber Daya Manusia, Teori dan Aplikasi, Alfabeta, Bandung

Ghozali, Imam. 2016. Aplikasi Analisis Multivariate Dengan Program IBM SPSS
23. Penerbit Universitas Diponegoro, Jakarta.

Hani Handoko. 2012, Manajemen Personalia dan Sumber Daya Manusia, Jakarta : F.E. UGM.

Juni, Priansa Donni. 2018. Perencanaan \&Pengembangan SDM. Alfabetha, Bandung.

Mangkunegara A.A. Anwar Prabu Mangkunegara. 2013. Manajemen Sumber Daya Manusia Perusahaan. Rosdakarya, Bandung.

Mangkunegara, A.A Anwar Prabu. 2012. Evaluasi Kinerja Sumber Daya Manusia. Bandung: PT. Refika Aditama.

Moeheriono, 2014, Pengukuran Kinerja Berbasis Kompetensi. Edisi Revisi, Jakarta: PT RajaGrafindo Persada

Mudrajad Kuncoro, 2013. "Metode Riset untuk Bisnis dan Ekonomi" Edisi 4. Jakarta: Erlangga.

Mulyono, Anton, M. 2011. Aktivitas Belajar. Yrama. Bandung

Nazir, Moh. 2013. Metode Penelitian. Bogor: Ghalia Indonesia.

Sedarmayanti. 2017. Sumber Daya Manusia. Aditama, Bandung.

Siagian, Sondang P. 2012. Manajemen Sumber Daya Manusia. Jakarta: Bumi Aksara.

Sudarmanto.2014. Kinerja dan Pengembangan Kompetensi SDM. Yogyakarta: Pustaka Pelajar.

Sugiyono. 2016. Metode Penelitian Kuantitatif, Kualitatif dan $R \& D$, Bandung: Alfabteha. .2017. Metode Penelitian Kombinasi (Mixed Methods), Bandung: Alfabeta

Sunyoto, Danang. 2012. Manajemen Sumber Daya Manusia. Center for Academic 
Publishing Service. Yogyakarta

Sutrisno, Edy. 2016. Manajemen Sumber Daya Manusia. Cetakan ke-8. Jakarta : Prenada Media Group

Wibowo. 2017. Manajemen Kinerja. RajaGrafindo Persada, Jakarta.

Sri Widodo Soedarso. 2015. Manajemen Sumberdaya Manusia : teori, prencanaan Sttrategi, isu-isu utama dan globalisasi. Bandung : Manggu Media

Veithzal Rivai \& Ella Jauvani Sagala. 2013. Manajemen Sumber Daya Manusia Untuk Perusahaan, PT Raja Garfindo, Jakarta

\section{Jurnal}

Anastasia Lisa Bintari. Pengaruh Kompetensi Dan Pengembangan Karir Terhadap Kinerja Karyawan Pada PT Purnama Indonesia Sidoarjo. Jurnal Ilmu Manajemen Volume 6 Nomor 4- Jurusan Manajemen Fakultas Ekonomi Universitas Negeri Surabaya, Vol. 6 No, 4 Tahun 2018.

Distyawaty Pengaruh Kompetensi Dan Pengembangan Karir Terhadap Kinerja Aparatur Pengawas Inspektorat Daerah Provinsi Sulawesi Tengah. 57 e Jurnal Katalogis, Volume 5 Nomor 4, April 2017.

Rizki Kurniadi, Pengaruh Kompetensi Dan Pengembangan Karir Terhadap Kinerja Guru SMK Negeri 1 Klego Kabupaten Boyolali. Jurusan Manajemen Bisnis Syariah Fakultas Ekonomi Dan Bisnis Islam Institut Agama Islam Negeri Surakarta 2017 